\title{
MODEL LATIHAN KETERAMPILAN GERAK PENCAK SILAT ANAK USIA 9-12 TAHUN
}

\section{A TRAINING MODEL FOR PENCAK SILAT MOVEMENT SKILLS OF CHILDREN AGED 9-12 YEARS}

\author{
Bayu Iswana, Siswantoyo \\ PPs UNY, Universitas Negeri Yogyakarta \\ bayusuroso94@yahoo.com, splc_fikuny@yahoo.com
}

\begin{abstract}
Abstrak
Penelitian ini bertujuan untuk menghasilkan model latihan keterampilan gerak pencak silat anak usia 9-12 tahun. Penelitian pengembangan mengadaptasi langkah-langkah penelitian pengembangan dari Borg \& Gall (1983, p.775), (1) pengumpulan informasi, (2) analisis hasil informasi, (3) pengembangan produk awal, (4) validasi ahli dan revisi tahap 1, (5) ujicoba skala kecil dan revisi, (6) ujicoba skala besar dan revisi tahap 2, (7) produk final. Uji coba skala kecil dilakukan terhadap anak Tapak Suci SD N 1 Padokan dan Tapak Suci SD Muhamadiyah Demangan. Uji coba skala besar dilakukan terhadap anak Pagar Nusa Sleman, Pagar Nusa Kota Yogyakarta yang berlatih di SD N Demangan, Persatuan Hati Bantul. Instrumen pengumpulan data, (1) wawancara, (2) skala nilai, (3) pedoman observasi model, (4) pedoman keefektifan model. Teknik analisis data yang digunakan yaitu analisis deskriptif kuantitatif dan diskriptif kualitatif. Isi dari hasil produk di dalamnya terdapat 6 model latihan, (1) kucing dan tikus, (2) bentengan, (3) gobak sodor, (4) jala ikan, (5) berburu burung, (7) elang dan anak ayam. Para ahli menyimpulkan bahwa di dalam model terdapat aspek kognitif, afektif dan psikomotor, sehingga model layak dan efektif untuk digunakan.
\end{abstract}

Kata Kunci: model, latihan, pencak silat usia 9-12 th

\section{Abstract}

This study aims to produce a training model for pencak silat (self-defence) movement skills of children aged 9-12 years. This research and development $(R \& D)$ study was conducted by adapting the $R \& D$ steps by Borg \& Gall (1983, p.775), i.e. (1) information collection, (2) information result analysis, (3) preliminary product development, (4) expert validation and stage 1 revision, (5) a smallscale tryout and a revision, (6) a large-scale tryout and stage 2 revision, and (7) final product. The small-scale tryout was conducted by involving participants of Tapak Suci SD N I Padokan and Tapak Suci SD Muhamadiyah Demangan. The large-scale tryout was conducted by involving participants of Pagar Nusa Sleman and Pagar Nusa Yogyakarta City carrying out training in SD N Demangan and Persatuan Hati Bantul.. The data collecting instruments included (1) interviews, (2) a score scale, (3) a model observation guide, and (4) a model effectiveness guide. The data were anlyzed using the quantitative and qualitative descriptive techniques. The contents of the product consist of six training models, i.e. (1) kucing dan tikus, (2) bentengan, (3) gobak sodor, (4) jala ikan, (5) berburu burung and (6) elang dan anak ayam.. The experts conclude that in the model there are cognitive, affective, and psychomotor aspects so that it is appropriate and effective to use.

Keywords: model, training, pencak silat, children aged 9 - 12 years 


\section{Pendahuluan}

Prinsip dasar olahraga pencak silat adalah membela diri yang di dalamnya terdapat nilai menyerang dan bertahan. Menyerang dan bertahan menjadi sebuah hal yang harus dimiliki oleh atlet pencak silat, ini yang akan menentukan kualitas seorang atlet pencak silat. Bertahan seperti mengelak, menghindari lawan untuk mengantisipasi serangan lawan, menjadi kunci pokok dalam konsep pertandingan pencak silat. Selain itu jelas ditegaskan bahwa nilai menyerang merupakan hal yang wajib dimiliki oleh atlet pencak silat. Gerakan menyerang bukan hanya seorang atlet pencak silat melakukan tendangan ataupun pukulan, namun yang mendasari dari gerakan ini bahwa bagaimana seorang atlet pencak silat dapat melakukan apa dan kapan jenis pukulan ataupun tendangan itu digunakan.

Pengenalan pada cabang olahraga pencak silat yang dilakukan di Indonesia umumnya berasal dari perguruan. Perguruan merupakan dasar ataupun hal yang tidak bisa lepas dari cabang olahraga pencak silat. Pembentukan gerakan yang tepat dan sesuai dengan apa yang menjadi kebutuhan anak akan sangat menentukan hasil keterampilan seorang anak terhadap kemampuannya.

Setiap perguruan memiliki pelatih yang mempunyai persepsi berbeda terhadap pembentukan gerak, khususnya pada anak usia 9-12 tahun. Hal ini ditunjukkan dari hasil wawancara pada saat kejuaraan antarsekolah SD, SMP, SMA sederajat se-DIY yang dilaksanakan di GOR UNY pada tanggal 24-27 April 2011 dan dikuatkan pada pertanyaan beberapa peserta pada penataran pelatih tingkat dasar pada tanggal 30 Desember tahun 2012, pelatih kecenderungan memberikan model seadanya, hampir semua pelatih memberikan model yang seharusnya diberikan kepada atlet remaja/dewasa, namun diberikan terhadap anak usia 9-12 tahun. Permasalahan ini menimbulkan anak dikemudian hari akan mengalami tingkat kebosanan dalam proses latihan. Kebosanan yang muncul ketika anak menginjak usia praremaja dan remaja yang seharusnya diarahkan kepada olahraga prestasi, menjadikan anak enggan melanjutkan untuk menjadi seorang atlet.

Materi yang diterima anak usia 9-12 tahun tidak lain adalah bagaimana konsep dalam olahraga pencak silat dapat tersampaikan dan diterima melalui aktivitas bermain. Tujuannya agar anak dapat melakukan aktivitas fisik sesuai dengan karakteristik anak, disamping itu kebutuhan dalam olahraga pencak silat juga dapat diterima oleh anak.

Melihat permasalahan yang secara rinci dijelaskan di atas perlu adanya suatu bentuk/ model latihan yang khusus untuk anak usia 9-12 tahun. Model latihan yang sesuai dan tepat dengan karakteristik anak usia 9-12 tahun diharapkan dapat membantu proses pembentukan keterampilan gerak pencak silat. Secara langsung dengan adanya model yang tepat membantu pelatih dalam memecahkan masalah yang sangat mendasar sehingga kebutuhan gerak anak dapat tercapai sesuai dengan karakteristik anak usia 9-12 tahun. Adanya model latihan keterampilan gerak pencak silat yang dikhususkan untuk anak usia 9-12 tahun merupakan jawaban yang sesuai dengan permasalahan yang dihadapi oleh para pelatih.

\section{Unsur Gerak Olahraga Pencak Silat}

Olahraga pencak silat merupakan gabungan dari beberapa unsur gerakan yang saling mendukung. Unsur gerak di dalam olahraga pencak silat mengandung nilai seni, serta menonjolkan sebuah keindahan gerak. Ada beberapa unsur gerak yang menurut Johansyah Lubis (2004, pp.8-33) yang dijelaskan secara rinci, di antaranya (1) kuda-kuda, (2) sikap pasang, (3) pola langkah, (4) belaan, (5) serangan, (6) tangkapan.

\section{Kuda-Kuda}

Istilah kuda-kuda sangat akrab digunakan dalam bela diri pencak silat. Posisi ini digambarkan seperti orang menunggang kuda. Kuda-kuda merupakan posisi dasar dalam melakukan teknik selanjutnya. Kuda-kuda adalah teknik yang memperlihatkan sikap dari kedua kaki dalam keadaan statis. Teknik ini digunakan untuk mendukung sikap pasang pencak silat. Kuda-kuda juga digunakan sebagai latihan dasar pencak silat untuk memperkuat otot-otot kaki. kuda-kuda dapat dibedakan menjadi beberapa klasifikasi antara lain.

Kuda-kuda ringan, yakni kuda-kuda dengan salah satu atau kedua kaki menopang sebagaian berat badan cenderung bersifat aktif. Kuda-kuda sedang, yakni sikap kuda-kuda dengan dua kaki menopang sebagian berat badan, bisa bersifat aktif ataupun pasif. Kuda-kuda berat, yakni sikap kuda-kuda yang salah satu atau kedua kaki menopang seluruh berat badan dan cenderung bersifat pasif. 


\section{Pola Langkah}

Langkah merupakan teknik gerak kaki dalam pemindahan dan pengubahan posisi untuk mendekati atau menjauhi lawan guna mendapatkan posisi yang lebih menguntungkan yang dikombinasikan dengan sikap tubuh dan tangan. Pola langkah digunakan apabila dua pesilat saling mencari poin pada saat bertanding, adanya pola langkah yang dibentuk secara benar memudahkan seseorang dalam melakukan tekanan ataupun keluar dari sebuah tekanan

Pola langkah merupakan hal yang pokok dalam sebuah pertandingan, dimana atlet pencak silat dalam melakukan serangan ataupun bertahan dapat menyusun strategi ataupun teknik yang akan dilakukan. Pengenalan pola langkah terhadap anak yang dikenalkan melalui bentuk bermain merupakan hal yang sesuai dengan kebutuhan anak, sehingga diharapkan nantinya atlet pencak silat pada saat remaja ataupun dewasa pola langkah ini sudah terpondasi secara baik dan benar. Terbentuknya pondasi pola langkah yang baik akan sangat mempermudah atlet dalam memenangkan sebuah pertandingan serta pola langkah akan sangat menentukan kecerdikan atlet pencak silat pada saat bertanding.

\section{Belaan}

Belaan adalah upaya untuk menggagalkan serangan dengan tangkisan atau menghindari lawan. Belaan terdiri dari dua macam yaitu tangkisan dan hindaran.

Tangkisan adalah suatu teknik belaan untuk menggagalkan serangan lawan dengan melakukan tindakan menahan serangan lawan menggunakan tangan, kaki, dan tubuh.

Hindaran adalah suatu teknik menggagalkan serangan lawan yang dilakukan tanpa menyentuh tubuh lawan.

\section{Serangan}

Serangan adalah gerakan yang dilakukan seorang atlet pencak silat yang bertujuan mendapatkan nilai dengan melakukan tendangan ataupun pukulan dengan sasaran yang sah sesuai peraturan pertandingan. Ada beberapa jenis serangan dalam olahraga pencak silat diantaranya.

Serangan tangan yakni serangan yang dilakukan dengan menggunakan pukulan, mengena pada bagian yang sah sesuai dengan peraturan pertandingan.
Tendangan yakni serangan yang dilakukan dengan menggunakan kaki, mengena pada bagian yang sah sesuai dengan peraturan pertandingan.

\section{Tangkapan}

Tangkapan merupakan teknik menangkap tangan, kaki, ataupun anggota badan lawan dengan satu atau dua tangan dan akan dilanjutkan dengan gerakan lain.

Beberapa penjelasan mengenai unsur yang dibutuhkan dalam cabang olahraga pencak silat. Peneliti mengambil kesimpulan bahwa unsur yang ada di dalam olahraga pencak silat haruslah termuat pada model latihan untuk anak. Penjelasan di atas mengarahkan model yang akan digunakan untuk anak usia 9-12 tahun menggunakan pendekatan permainan tradisional harus memenuhi unsur gerak yang telah dijelaskan di atas, diantaranya kuda-kuda, pola langkah, sikap pasang, belaan, serangan.

\section{Teori Belajar}

Usia 9-12 tahun/setara dengan siswa SD kelas atas, adalah suatu pemikiran ideal untuk menerangkan apa, bagaimana, dan mengapa belajar itu, serta persoalan lain tentang belajar pada anak. Teori belajar dikembangkan dari kenyataan bahwa manusia secara alami memiliki kemampuan dan kemauan untuk belajar yang luar biasa. Manusia telah mengembangkan peradaban, ilmu pengetahuan, dan teknologi sebagai wujud dari proses belajar setiap individu memiliki cara dan hasil belajar yang berbedabeda.

Teori belajar pada anak usia 9-12 tahun diperlukan untuk berbagai kepentingan, seperti (a) untuk menyusun kegiatan, (b) untuk mendiagnosis problem yang muncul, (c) untuk mengevaluasi hasil, (d) sebagai kerangka penelitian. Kegiatan pada anak sebaiknya didasarkan atas teori belajar dan berbagai hasil penelitian tentang belajar anak. Demikian pula untuk mengatasi suatu persoalan yang muncul di kelas, seperti adanya anak-anak yang pemalu, tidak mau ditinggal orang tuanya, atau nakal, pelatih perlu menggunakan acuan teori belajar, misalnya teori Classical Conditioning. Teori belajar juga diperlukan untuk mengevaluasi hasil belajar. Sebagai contoh, untuk mengukur perkembangan kognitif anak, pelatih dapat menggunakan teori perkembangan kognitif.

Pemahaman mengenai teori belajar merupakan bentuk landasan dalam pengembangan model latihan keterampilan gerak pencak silat. 
Hal ini berkaitan dengan kajian tentang aspek bagaimana anak latih dalam menerima materi latihan dan dengan pendekatan apa latihan tersebut dapat tersampaikan sesuai dengan karakteristik anak usia 9-12 tahun. Teori belajar merupakan landasan pokok dalam menyusun desain, mengembangkan desain dengan memanfaatkan media dan melaksanakan prosesnya. Pemahaman tentang beberapa teori belajar dapat dimanfaatkan untuk melakukan proses secara sistematis, penemuan-penemuan, melahirkan hipotesis, dan dapat menjelaskan sesuai yang dibutuhkan. Teori belajar merupakan teori yang menaruh perhatian pada hubungan antarvariabel-variabel yang menentukan hasil belajar. Teori belajar bersifat deskriptif, artinya mendeskripsikan bagaimana proses belajar berlangsung dalam diri seseorang. Menurut Cohen (Rahman, 2006, p.23) bahwa belajar mengandung arti perubahan perilaku/kemampuan yang bertahan dalam periode waktu tertentu, dan tidak semata disebabkan oleh proses pertumbuhan dan kematangan. Berikut adalah teori belajar dari beberapa ahli yang sesuai dengan kebutuhan serta sebagai bahan kajian teori dalam proses penelitian.

\section{Teori Jejak Memori (Gestalt)}

Menurut Gestalt (Hergenhanh \& Olson, 2008, p.330) jejak Memori adalah sistem fisik yang menghasilkan kekuatan medan diperoleh dari pengalaman masa lalu yang akan mempengaruhi semua proses serupa di masa yang akan datang. Penjelasan Gestalt mengenai jejak memori memberikan sebuah gambaran terhadap penelitian ini bahwa pemberian ataupun penanaman yang berhubungan dengan aspek kognitif, afektif dan psikomotor. Pemberian sebuah keterampilan yang disesuaikan dengan tujuan utama dimana proses itu akan dibutuhkan dan diingat secara permanen khususnya keterampilan gerak. Pembentukan yang permanen pada kerterampilan gerak diharapkan dapat bermanfaat terhadap tujuan utama.

Keterampilan gerak pencak silat yang dimiliki sejak usia 9 tahun diharapkan proses pembentukan ini akan bermanfaat terhadap tujuan utama. Tujuan utama dari pembentukan keterampilan gerak pencak silat sejak usia 9 tahun ini diharapkan di kemudian hari apa yang didapat dari proses pembentukan akan bermanfaat di masa yang akan datang, hal ini sejalan dengan teori jejak memori yang dikemukakan oleh Gestalt.

\section{Teori Pengetahuan Empiristik (Aristoteles)}

Menurut Aristoteles (Hergenhanh \& Olson, 2008, p.34) merumuskan hukum asosiasi, bahwa pengalaman atau ingatan akan satu objek cenderung menimbulkan ingatan akan hal serupa dengan objek tersebut. Lebih lanjut menjelaskan bahwa Aristoteles menganggap kesan indra adalah basis dari semua pengetahuan.

Sejalan dengan pemikiran teori ini bahwa keterampilan gerak pencak silat membutuhkan berbagai indra yang terlibat di dalamnya. Anak akan lebih terpacu dalam melakukan kegiatan apabila lingkungan yang ada kondusif untuk belajar. Suasana bermain yang mendukung seperti teman, jenis kegiatan, tempat kegiatan yang dirasakan oleh anak akan benar memberi dorongan positif.

\section{Teori Kesiapan (Thorndike)}

Menurut Thorndike (Hergenhanh \& Olson, 2008, p.34) menjelaskan beberapa bagian tentang hukum kesiapan yakni "Apabila seseorang siap untuk melakukan suatu tindakan, maka jika dilakukan akan memuaskan, namun jika seseorang belum siap melakukan suatu tindakan tetapi dipaksa melakukannya, maka jika dilakukan akan menjengkelkan".

Penjelasan Thorndike tentang teori kesiapan seorang individu bahwa, ketika anak mendapatkan sebuah kebutuhan gerak pada masa itu dan kebutuhan itu didapatkan sesuai dengan kebutuhan anak waktu itu maka, hasil yang didapatkan oleh anak adalah sebuah kepuasan dan pada prosesnya anak akan melakukan dengan maksimal. Berbanding terbalik, apabila anak tidak mendapatkan kebutuhan geraknya pada waktu itu, maka hasil yang diperoleh membuat anak merasa jengkel, yang berakibat muncul sebuah perasaan ketidaknyamanan pada diri anak.

\section{Teori Behavior}

Teori ini merupakan teori belajar yang berdasarkan pada perubahan tingkah laku. Behaviourisme adalah pandangan yang menyatakan bahwa perilaku harus dijelaskan melalui pengalaman yang dapat diamati. Teori ini menekankan pada pola perilaku baru yang diulangulang sampai menjadi otomatis. Menurut Pavlov (Purnamawati, 2011, p.37) ada beberapa prinsip pembelajaran behavior antara lain: (1) menekankan perhatian pada perubahan perilaku yang dapat diamati setelah seseorang diberi perlakuan, (2) perilaku dapat dikuatkan atau 
dihentikan melalui ganjaran atau hukuman, (3) pengajaran direncanakan dengan menyusun tujuan instruksional yang dapat diukur atau diamati, (4) guru tidak perlu tahu pengetahuan apa yang telah diketahui dan apa yang terjadi pada proses berfikir seseorang.

Pengertian Olahraga Tradisional

Menurut Eylier dan Zakrajek (Iswanto, 2009 , p.9) istilah sport berasal dari kata disport, muncul pertama kali dalam perpustakaan, pada tahun 1303 yang berarti "sport, past time, recreation and leasure", secara esensial pengertiannya berkaitan dengan tiga unsur pokok yaitu bermain, latihan fisik dan kompetisi. Menurut Cholik (2002, p.152) olahraga adalah proses sistematik yang berupa segala kegiatan atau usaha yang dapat mendorong, membangkitkan, mengembangkan dan membina potensi jasmaniah dan rohaniah seseorang sebagai perorangan atau anggota masyarakat dalam bentuk permainan, perlombaan, dan kegiatan jasmani yang intensif untuk memperoleh reaksi kemenangan dan prestasi puncak dalam rangka pembentukan manusia indonesia seutuhnya yang berkualitas berdasarkan Pancasila. Menurut Giriwijoyo (2007, p.85) olahraga adalah serangkaian gerak raga yang teratur dan terencana untuk memelihara gerak. Olahraga sebagai alat untuk memelihara dan membina kesehatan, tidak dapat ditinggalkan dan harus selalu di ulang-ulang.

Menurut Komisi Disiplin Ilmu Olahraga $(2000$, p.7) olahraga adalah bentuk perilaku manusia yang spesifik. Arah dan tujuan berolahraga termasuk waktu dan alokasi kegiatan dilaksanakan sedemikian rupa sehingga sebagai bukti bahwa olahraga itu merupakan sebuah fenomena yang relevan dengan kehidupan sosial, olahraga juga ekspresi budaya berkarya pada manusia.

Menurut Ardiwinata (2006, p.1) olahraga tradisional merupakan warisan kebudayaan nenek moyang bangsa Indonesia. Olahraga tradisional harus memenuhi dua persyaratan yaitu berupa "olahraga" dan sekaligus "tradisional" baik dalam memiliki tradisi yang telah berkembang selama beberapa generasi, maupun dalam arti sesuatu yang terkait dengan tradisi budaya suatu bangsa secara lebih luas. Nilai-nilai budaya yang terkandung di dalam bentuk olahraga tradisional adalah penghargaan pada usaha yang keras untuk mencapai prestasi unggul, penghargaan pada prestasi orang lain.
Olahraga tradisional perlu dikembangkan demi ketahanan budaya bangsa, karena harus disadari bahwa kebudayaan merupakan nilai-nilai luhur bagi bangsa Indonesia. Selain itu olahraga tradisional merupakan salah satu aspek yang perlu mendapatkan prioritas utama untuk dilindungi, dibina, dikembangkan, diberdayakan yang selanjutnya diwariskan agar tidak hilang oleh perkembangan jaman atau hilang diambil negara lain. Beberapa penjelasan mengenai teori olahraga tradisional bahwa olahraga tradisional merupakan serangkaian aktivitas fisik dengan menggunakan permainan tradisional yang dilakukan secara teratur serta memiliki tujuan yang di dalamnya terdapat nilai-nilai dari jenis permainan yang dimainkan oleh seseorang/beberapa orang dengan tujuan menjaga kebugaran dan kelestarian permainan tersebut agar tidak termakan oleh perkembangan jaman.

\section{Prinsip-Prinsip Olahraga Tradisional}

Menurut Ardiwinata (2006, p.4) dalam olahraga tradisional perlu diperhatikan adanya pemilahan antara permainan anak dengan permainan orang dewasa. Olahraga bagi orang dewasa termasuk dalam berbagai lomba seperti tarik tambang, karapan sapi dan sebagainya. Sedangkan olahraga tradisional untuk anak-anak yang pada penelitian ini ditujukan kepada cabang olahraga pencak silat bersifat permainan yang di dalamnya terdapat nilai-nilai beladiri, artinya dalam permainan terdapat serang dan membela. Pemilihan permainan tradisional sesuai dengan apa yang menjadi tujuan utama yaitu memberikan nilai-nilai beladiri pada cabang olahraga pencak silat berdasarkan pada jenis permainan yang disesuaikan dengan kebutuhan pencak silat, terdapat komponen biomotor yang dibutuhkan dalam cabang olahraga pencak silat sehingga permainan sejalan dengan apa yang menjadi kebutuhan. Menurut Hariono (2006, p.41) komponen biomotor yang dibutuhkan dalam cabang olahraga pencak silat yaitu kecepatan, ketahanan, fleksibilitas, kekuatan, koordinasi.

Dijelaskan lebih lanjut mengenai penjelasan komponen biomotor menurut Sukadiyanto (2002, p.57): (1) ketahanan, (2) kecepatan, (3) fleksibilitas, (4) kekuatan, (5) koordinasi.

\section{Ketahanan}

Istilah ketahanan atau daya tahan ditinjau dari kerja otot adalah kemampuan otot atau 
sekelompok otot dalam jangka waktu tertentu, sedangkan pengertian ketahanan dari sistem energi adalah kemampuan kerja organ-organ tubuh dalam jangka waktu tertentu. Komponen biomotor ketahanan pada umumnya digunakan sebagai salah satu tolak ukur untuk mengetahui tingkat kebugaran jasmani olahragawan.

\section{Kecepatan}

Kecepatan adalah kemampuan otot atau sekelompok otot untuk menjawab rangsang dalam waktu secepat (singkat) mungkin. Kecepatan sebagai hasil perpaduan dari panjang ayunan tungkai dan jumlah langkah, dimana gerakan panjang ayunan dan jumlah langkah merupakan serangkaian gerak yang sinkron dan kompleks dari sistem neuromuskuler. Kecepatan merupakan salah satu komponen dasar biomotor yang diperlukan dalam setiap cabang olahraga. Setiap aktivitas olahraga baik yang bersifat permainan, perlombaan, maupun pertandingan selalu memerlukan komponen biomotor kecepatan. Untuk itu kecepatan merupakan salah satu unsur biomotor yang harus dilatihkan dalam upaya mendukung pencapaian prestasi olahragawan.

\section{Fleksibilitas}

Fleksibilitas mengandung pengertian, yaitu luas gerak suatu persendian atau beberapa persendian. Ada dua macam fleksibilitas yaitu, (a) statis, (b) dinamis. Pada fleksibilitas statis ditentukan oleh ukuran dari luas gerak (range of motion) satu atau beberapa persendian. Sebagai contoh untuk mengukur luas gerak persendian tulang belakang dengan cara sit and reach test. Sedangkan pada fleksibilitas dinamis adalah kemampuan seseorang dalam bergerak dengan kecepatan tinggi. Sebagai contoh olahraga senam perlombaan.

\section{Kekuatan}

Pengertian kekuatan secara umum adalah kemampuan otot atau sekelompok otot untuk mengatasi beban atau tahanan. Pengertian secara fisiologi, kekuatan adalah kemampuan neuromuscular untuk mengatasi tahanan beban luar dan beban dalam. Manfaat dari latihan kekuatan bagi olahragawan diantaranya untuk (a) meningkatkan kemampuan otot dan jaring-an, (b) mengurangi cedera pada olahragawan, (c) meningkatkan prestasi, (d) terapi pada rehabilitasi pengutan otot, (e) membantu mempelajari atau penguasaan teknik.

\section{Koordinasi}

Koordinasi terdiri dari dua katagori yaitu koordinasi umum dan khusus, koordinasi umum merupakan kemampuan seluruh tubuh dalam menyesuaikan dan mengatur gerakan secara stimulan pada saat melakukan suatu gerak (Sukadiyanto, 2002, p.138). Sedangkan koordinasi khusus yaitu koordinasi antara beberapa anggota badan, yaitu kemampuan untuk mengkoordinasikan gerak dari sejumlah anggota badan secara stimulant (Sage dalam Sukadiyanto, 2002, p.138).

Olahraga tradisional yang akan digunakan sebagai instrumen pada penelitian ini adalah gobak sodor, bentengan, kucing dan tikus, berburu burung, jala ikan serta elang dan anak ayam. Pemilihan permainan disesuaikan dengan tujuan serta jenis dari kedua variabel yang saling berhubungan, sehingga pada pemilihan model ini telah dilakukan peninjauan agar manfaat serta tujuan dapat sesuai dengan harapan.

\section{Hakikat Bermain}

Bermain merupakan upaya memenuhi tiga kebutuhan sekaligus yaitu kebutuhan fisik, emosi, dan stimulasi/pendidikan. Seorang anak yang biasa berinteraksi dengan teman sebayanya mempunyai tingkat kemantangan dan kesiapan yang baik dalam menerima pendidikan yang lebih rumit. Berbagai pendapat tentang definisi bermain yang dikemukakan oleh para ahli. Bermain (play) merupakan istilah yang digunakan secara bebas sehingga arti utamanya mungkin hilang. Kegiatan yang dilakukan untuk kesenangan yang ditimbulkannya tanpa mempertimbangkan hasil akhir. Bermain dilakukan secara suka rela dan tidak ada paksaan atau tekanan dari luar/kewajiban.

Menurut Komisi Disiplin Ilmu Keolahragaan (2000, p.9), bermain merupakan dorongan naluri, fitrah manusia, dan pada anak merupakan keniscayaan sosiologis dan biologis. Ciri lain yang amat mendasar yakni kegiatan itu dilakukan secara suka rela, tanpa paksaan, dalam waktu luang. Di dalamnya juga terkandung nilai pendidikan sehingga perlu dimanfaatkan sebagai upaya menuju pendewasaan melalui pemberian rangsangan yang bersifat menyeluruh, meliputi aspek fisik, mental, sosial, dan moral yang berguna pada pencapaian pertumbuhan dan perkembangan secara moral dan wajar. Menurut Hizinga (Soetoto, 1999, p.3), bermain merupakan perbuatan atas kemauan sendiri yang dikerjakan dalam batas-batas tem- 
pat dan waktu yang telah ditentukan, diikuti oleh perasaan.

Sejalan dengan pendapat mengenai bermain ada teori yang menjelaskan mengapa anak melakukan bermain antara lain. Para ahli mengemukakan beberapa teori tentang bermain (Soetoto, 1999, p.9) antara lain: (1) Teori kelebihan tenaga dari Hebert Spencer, menjelaskan bahwa tenaga yang berlebihan pada anak menuntut jalan keluar dan dapat disalurkan dalam permainan; (2) Teori rekreasi dari Schaller dan Lazarus, mengemukakan bahwa permainan itu adalah keasikan dalam bentuk bukan bekerja dan bermaksud untuk bersenang-senang serta istirahat. Bermain dilakukan orang setelah lelah bekerja dan bertujuan menyegarkan kembali jiwa dan raganya; (3) Teori Atavisme dari Stanely Hall, menerangkan bahwa bermain adalah ulangan dari kehidupan nenek moyang. Perkembangan bermain anak nampak bahwa jenis bermainnya meniru sosok sebagai pemburu, petani, pedagang. Hal ini disebabkan oleh jiwa anak telah mewarisi dari jiwa nenek moyangnya atau dikarenakan pemikiran anak sejalan dengan manusia terdahulu; (4) Teori persiapan atau latihan dari Groos, teori ini memandang bermain sebagai latihan manusia sebelum menuju masa dewasa untuk menyiapkan beberapa fungsi keperluan kehidupan. Sebagai contoh, umumnya anak perempuan bermain boneka hal ini menunjukan anak mempersiapkan menjadi ibu dari anak-anak dikemudian hari. Sedangkan anak laki-laki bermain perangperangan yang bertujuan melindungi diri; (5) Teori Kataris dari Aristoteles, memandang bahwa anak bermain sebagai media untuk menyalurkan luapan emosi yang tertahan dan menyalurkan perasaan yang tidak dapat dinyatakan ke arah yang baik.

Teori bermain di atas menunjukkan ada sebuah perbedaan sudut pandang mengenai filosofi bermain, namun penafsiran para ahli merupakan penyempurnaan mengenai arti dan fungsi bermain. Semuanya apabila dilihat secara kebutuhan anak merupakan hal yang pasti ada dalam kehidupan perkembangan anak.

\section{Metode}

Penelitian ini menggunakan metode penelitian dan pengembangan (Research and Development) merupakan metode penelitian yang digunakan untuk menghasilkan produk tertentu, dan menguji keefektifan produk tersebut. Penelitian pengembangan ini dilakukan untuk menghasilkan sebuah model latihan ke- terampilan gerak pencak silat anak usia 9-12 tahun setara siswa sekolah dasar kelas atas.

Menurut Borg \& Gall (1983, p.772), Research and Development adalah proses yang digunakan untuk mengembangkan dan memvalidasi produk-produk pendidikan baik produk yang berupa objek material seperti buku teks, $C D$ pembelajaran maupun produk yang berupa proses dan prosedur yang ditemukan seperti metode mengajar atau metode mengorganisir pengajaran

\section{Waktu dan Tempat Penelitian}

Penelitian ini dilaksanakan di tiga perguruan pencak silat yang berada di Yogyakarta. Perguruan Persatuan Hati, Pagar Nusa dan Tapak Suci. Dilaksanakan selama dua bulan, dimulai pada bulan November 2012 sampai dengan bulan Januari 2013.

\section{Prosedur Pengembangan}

Pengumpulan hasil riset dan informasi, perencanaan, mengembangkan produk awal, uji coba awal, revisi penyusunan produk utama, uji coba lapangan utama, revisi penyusunan produk operasional, uji coba produk oprasional, revisi produk final.

\section{Data, Intrumen, dan Teknik Pengumpulan}

Data yang diperoleh dalam penelitian dan pengambangan ini berupa data kualitatif dan kuantitatif. Data kualitatif berasal dari (a) hasil wawancara pelatih, (b) kekurangan model latihan dari pakar dan ahli, (c) masukan materi dari ahli terhadap model latihan. Data kuantitatif diperoleh dari (a) penilaian pakar terhadap draf produk, (b) lembar observasi pelatih, pakar dan ahli, (c) lembar efektivitas produk. Datadata tersebut digunakan untuk mengevaluasi model latihan pencak silat anak usia 9-12 tahun.

Wawancara Teknik pengumpulan data pertama yang digunakan yaitu berinteraksi langsung dengan yang bersangkutan. Definisi dari teknik komunikasi langsung adalah pengumpulan data yang dilakukan melalui hubungan komunikasi secara langsung yang disampaikan secara lisan (Hadari \& Martini 2006, p.98).

Skala nilai, digunakan untuk menilai model latihan pencak silat yang dikembangkan sebelum pelaksanaan uji coba skala kecil. Setelah ahli memberikan persetujuan sekaligus menilai tentang model latihan pencak silat anak usia 9-12 tahun sudah mengacu pada skala nilai, baru model latihan dapat diujicobakan 
dalam skala kecil. Kategori yang dimaksud dalam skala ini adalah kategori berskala dua, "Ya" dan "Tidak". Penggunaan skala nilai ini, bilamana muncul gejala atau unsur-unsur yang terdapat dalam klasifikasi data untuk mengiyakan ahli "Ya" dan "Tidak" dengan menandai simbol cek "لV" (Nawawi \& Hadari, 2006, pp.79-81). Apabila gejala atau unsur seperti yang terdapat dalam unsur klasifikasi data dinyatakan "Ya" maka nilainya 1 (satu) apabila dinyatakan "Tidak" sesuai maka nilainya 0 (nol).

Teknik pengumpulan data dengan menggunakan observasi tidak langsung, teknik observasi tidak langsung merupakan cara mengumpulkan data yang dilakukan melalui pengamatan dan pencatatan dari gejala-gejala yang tampak pada objek penelitian yang dilakukan setelah peristiwa, keadaan terjadi (Nawawi \& Hadari 2006, pp.67-68). Pengamatan dan pencatatan dilakukan menggunakan daftar cek dan peralatan ekektronik, peralatan elektronik yang digunakan dalam penelitian ini yaitu handycam, hal ini bertujuan agar pengamatan lebih objektif terhadap subjek yang diteliti ketika proses dilakukan. Untuk menggunakan daftar cek harus terlebih dahulu menjabarkan variabel penelitian secara lengkap yang di dalamnya terdapat unsur di dalam setiap gejala. Rincian gejala dan unsur-unsur disusun secara teratur menjadi suatu daftar sebagai urutan klasifikasi data yang akan diamati muncul atau tidaknya di dalam suatu peristiwa, keadaan/kejadian yang berkenan dengan masalah penelitian (Nawawi \& Hadari 2006, pp.7677). Alat bantu berupa peralatan elektronik, Nawawi \& Hadari (2006, p.83) menjelaskan bahwa apabila suatu peristiwa atau kejadian terjadi satu kali atau tidak berulang ulang bahkan dilakukan secara singkat, observasi kerap dilakukan secara tidak langsung. Untuk itu diperlukan alat pembantu berupa alat elektronik yang jenisnya disesuaikan dengan keperluannya. Agar peneliti dapat mengetahui hal yang sekiranya ragu akan kebenarannya peneliti menggunakan alat elektronik berupa handycam, dengan alat ini setiap kegiatan tercatat sesuai dengan apa yang terjadi. Penggunaan alat juga sangat mempengaruhi hasil kegiatan sehingga peneliti bekerja sama dengan orang yang kompeten terhadap oprasional alat ini. Sudut pandang, jumlah kamera ditentukan oleh peneliti agar unsur yang diperlukan terhadap tujauan penelitian dapat diraih dengan hasil yang diinginkan.

\section{Teknik Analisis Data}

Teknik analisis data yang digunakan yaitu analisis deskriptif kuantitatif dan kualitatif. Analisis deskriptif kuantitatif digunakan untuk menganalisis data-data yaitu: (a) data skala nilai berupa hasil penilaian para ahli/pakar terhadap model latihan sebelum draf diujicobakan, (b) data hasil observasi para ahli/pakar terhadap model latihan. Sedangkan analisis deskriptif kualitatif dilakukan terhadap: (a) data masukan dan kekurangan model latihan baik setelah dilakukan uji coba ataupun sebelum. Draf model latihan dinyatakan layak untuk dilakukan uji coba dalam skala kecil apabila para ahli/pakar telah memberikan validasi dan menyatakan semua item dianggap sesuai dengan cara memberi tanda $(\sqrt{ })$ dengan nilai 1 (satu) pada kolom sesuai. Namun jika ahli/pakar berpendapat bahwa item klasifikasi tidak sesuai cara memberi tanda $(\sqrt{ })$ yaitu nilai $0(\mathrm{nol})$ maka perlu dilakukan tinjauan dan pengkajian ulang terhadap model latihan untuk dilakukan revisi. Hasil observasi (ya) mendapat nilai 1 (satu) dan hasil observasi tidak mendapat nilai 0 (nol). Hasil penilaian terhadap item-item observasi dijumlahkan, kemudian ditotal nilainya dikonversikan untuk mengetahui kategorinya. Pengkonversian nilai dilakukan dengan mengikuti standar Penilaian Acuan Patokan (PAP). Umumnya kriteria nilai yang digunakan dalam bentuk rentang skor sebagai berikut

Tabel 1. Pengonversian Acuan Patokan.

\begin{tabular}{ccc}
\hline Skor Nilai & Katagori & Keterangan \\
\hline $80 \%-100 \%$ & A & Sangat Bik \\
$70 \%-79 \%$ & B & Baik \\
$60 \%-69 \%$ & C & Cukup Baik \\
$45 \%-59 \%$ & D & Kurang Baik \\
$<44 \%$ & E & Sangat Kurang Baik \\
\hline
\end{tabular}

\section{Hasil Penelitian dan Pembahasan}

\section{Analisis Data Kucing dan Tikus}

Penilaian observasi ahli materi terhadap model kucing dan tikus bahwa model ini masuk dalam katagori yang sangat baik. Beberapa ahli mempunyai pendapat yang sama dan menilai model ini sangat efektif untuk menanamkan kebutuhan yang ada dalam olahraga pencak silat meliputi komponen biomotor antara lain kekuatan, ketahanan, kecepatan, fleksibilitas dan kordinasi.

Selain itu model juga dapat mengembangkan ranah afektif seperti menanamkan 
unsur menyerang dan bertahan yang dibutuhkan dalam olahraga pencak silat. Kemudian model juga mampu mengembangkan ranah kognitif seperti memunculkan ide baru, menemukan pengalaman dan hal penting yaitu bagaimana anak mempertahankan kemenangan dan cara apa yang harus dilakukan untuk mempertahankannya, tidak hanya mempertahankan kemenangan namun ranah kognitif seperti bagaimana anak untuk mencari kemenangan juga termuat dalam model ini. Selain itu model ini mampu memberikan serta menanamkan kerja sama, keberanian penjaga dalam melakukan serangan memasuki lingkaran yang bermanfaat menanamkan nilai menyerang terhadap anak. Disisi lain anak juga melakukan pertahanan ketika melakukan penjagaan terhadap tikus yang dikejar oleh kucing.

Sesuai dengan manfaat penelitian bahwa model ini setelah dilakukan berbagai proses seperti pengujian draf, ujicoba, dan dilakukan analisis, bahwa model ini layak digunakan untuk melatih anak usia 9-12 tahun pada cabang olahraga pencak silat.

\section{Analisis Data Bentengan}

Penilaian observasi ahli materi terhadap model bentengan bahwa model ini masuk dalam katagori yang sangat baik. Beberapa ahli mempunyai pendapat bahwa menilai model ini sangat efektif untuk menanamkan kebutuhan yang ada dalam olahraga pencak silat meliputi komponen biomotor antara lain kekuatan, ketahanan, kecepatan, kelincahan, fleksibilitas dan kordinasi. Model ini menekankan pada nilai menyerang dan bertahan sehingga dalam pelaksanaannya kompetisi anak sangat baik dan apa yang menjadi kebutuhan anak seperti rasa senang, tanpa paksaan dapat tertuangkan melalui permainan ini.

Kemudian model juga mampu mengembangkan ranah kognitif seperti memunculkan ide baru, menemukan pengalaman, bagaimana anak perfikir untuk melakukan tindakan ketika anak dihadapi dengan permasalahan di lapangan. Sehingga anak mampu menyelesaikan permasalahan yang dihadapi sesuai dengan aturan yang telah ditentukan.

Penjelasan lebih lanjut bahwa model bentengan ini sama halnya dengan prinsip bermain dalam olahraga pencak silat, selain itu ada kesamaan mengenai unsur budaya, artinya bahwa permainan bentengan merupakan permainan tradisional yang perlu untuk dilestarikan keberadaanya, sama halnya dengan olahraga pencak silat. Model bentengan memiliki kesamaan yang hampir keseluruhan sama dengan olahraga pencak silat, seperti, (a) olahraga, (b) budaya, (c) beladiri.

\section{Olahraga}

Olahraga merupakan sebuah aktivitas yang melibatkan otot-otot besar, melihat serta membandingkan antara model bentengan dengan olahraga pencak silat semuanya melibatkan aktivitas otot besar, dan mempunyai kesamaan mengenai komponen biomotor yang telah dijelaskan di atas seperti kecepatan, kelincahan, kordinasi, dan kekuatan. Contoh ini memberikan kejelasan mengenai kesamaan antara model bentengan dengan olahraga pencak silat sehingga model bentengan sangatlah tepat digunakan dalam melatih keterampilan gerak pencak silat anak usia 9-12 tahu sesuai dengan beberapa kesamaan mengenai olahraga.

Budaya

Sesuai dengan semboyan di dalam sebuah tujuan yang dilihat dari mata budaya bahwa, pencak silat merupakan budaya bangsa Indonesia. Ini terlihat jelas dimana dalam lirik lagu Mars IPSI yang ditegaskan "Bangsa yang besar adalah bangsa yang mencintai budayanya sendiri" dilanjutkan di bait lain bahwa pencak silat merupakan budaya bangsa. Dari kenyataan yang ada benar dikatakan apabila pencak silat merupakan cermin budaya yang kuat bangsa Indonesia. Secara langsung dengan melestarikan olahraga pencak silat dengan sendirinya kita melestarikan budaya indonesia.

Berbicara olahraga tradisional sangatlah kental dengan budaya Indonesia. Olahraga tradisional kini kian pudar dimakan waktu, tujuan peneliti menguak sebuah model dengan menggunakan olahraga tradisional salah satunya menjaga warisan budaya bangsa agar olahraga yang dianggap sudah tidak bermanfaat dapat dikaji dan dilihat mengenai manfaat yang ada. Pemilihan menyatukan kedua olahraga sudah dikaji dan didiskusikan mengenai manfaat serta tujuannya.

Dilihat dari penjelasan di atas dapat diambil sebuah hasil pemikiran bahwa olahraga pencak silat dan model bentengan mempunyai kesamaan yang kuat dari sisi budaya.

\section{Beladiri}

Prinsip kerja model bentengan adalah menjaga benteng dan menyerang benteng. Pelaksanaannya bahwa di dalam model ini me- 
muat sebuah nilai menyerang, mempertahankan diri, yang merupakan konsep dasar dari beladiri. Dilihat dan dikaji melalui kesamaan dengan olahraga pencak silat sangat kuat kaitannya dari kedua olahraga ini.

\section{Analisis Data Gobak Sodor}

Hasil penilaian ahli materi menunjukan bahwa model latihan ini termasuk dalam kategori yang sangat baik. Jenis olahraga ini juga dinilai sangat efektif untuk mentransfer tujuan yang akan dihasilkan. Secara khusus ahli materi usia dini menjelaskan bahwa model latihan ini sangat sesuai untuk digunakan dalam proses latihan keterampilan gerak pencak silat.

Ahli mempunyai pendapat yang sama dan menilai model ini sangat efektif untuk menanamkan kebutuhan yang ada dalam olahraga pencak silat meliputi komponen biomotor antara lain kekuatan, ketahanan, kecepatan, fleksibilitas, kelincahan dan koordinasi. Selain itu model juga dapat mengembangkan ranah afektif seperti menanamkan unsur menyerang dan bertahan yang dibutuhkan dalam olahraga pencak silat.

Kemudian model juga mampu mengembangkan ranah kognitif seperti memunculkan ide baru, menemukan pengalaman dan hal penting yaitu bagaimana anak mempertahankan kemenangan dan cara apa yang harus dilakukan untuk mempertahankanya, tidak hanya mempertahankan kemenangan namun ranah kognitif seperti bagaimana anak untuk mencari kemenangan juga termuat dalam model ini.

Kesamaan yang terjadi antara model gobak sodor dengan olahraga pencak silat meliputi jenis gerakan, konsep permainan mencerminkan adanya sebuah ikatan yang kuat antar keduanya sehingga dapat disimpulkan model sangat sesuai digunakan untuk melatih keterampilan gerak pencak silat anak usia 9-12 tahun.

\section{Analisis Data Jala Ikan}

Ahli menilai bahwa model ini termasuk dalam katagori yang sangat baik. Beberapa ahli mempunyai pendapat yang sama dan menilai model ini sangat efektif untuk menanamkan kebutuhan yang ada dalam olahraga pencak silat meliputi komponen biomotor antara lain kekuatan, ketahanan, kecepatan, fleksibilitas dan kordinasi.

Selain itu model juga dapat mengembangkan ranah afektif seperti menanamkan unsur menyerang dan bertahan yang dibutuhkan dalam olahraga pencak silat. Unsur ini dapat melekat pada anak sehingga di kemudian hari ketika menjadi atlet pencak silat mempunyai unsur menyerang dan bertahan yang kuat.

Kemudian model juga mampu mengembangkan ranah kognitif, ranah kognitif yang diperoleh dari model ini seperti bagaimana anak melakukan tindakan untuk memenangkan sebuah pertandingan. Pencapaian kemenangan tidak semata-mata tertuju pada pemenang. Namun keberhasilan tindakan anak terhadap apa yang dilakukan dan hasilnya sesuai dengan aturan menjadi pengertian secara umum.

Kemudian terdapat masukan dari ahli agar gambar ketika melakukan gerakan menyerang dan bertahan diperlambat, tujuanya agar pelatih akan lebih mengerti ketika melihat video.

\section{Analisis Data Berburu Burung}

Penilaian observasi ahli materi terhadap model berburu burung bahwa model ini masuk dalam kategori yang sangat baik. Beberapa ahli mempunyai pendapat yang sama dan menilai model ini sangat efektif untuk menanamkan kebutuhan yang ada dalam olahraga pencak silat meliputi komponen biomotor antara lain kekuatan, ketahanan, kelincahan, kecepatan, fleksibilitas dan kordinasi.

Selain itu model juga dapat mengembangkan ranah afektif seperti menanamkan unsur menyerang dan bertahan yang dibutuhkan dalam olahraga pencak silat. Unsur ini dapat melekat pada anak sehingga dikemudian hari ketika menjadi atlet pencak silat mempunyai unsur menyerang dan bertahan yang kuat.

Kemudian model juga mampu mengembangkan ranah kognitif seperti memunculkan ide baru, menemukan pengalaman dan hal penting yaitu bagaimana anak mempertahankan kemenangan dan cara apa yang harus dilakukan untuk mempertahankannya, tidak hanya mempertahankan kemenangan namun ranah kognitif seperti bagaimana anak untuk mencari kemenangan juga termuat dalam model ini.

Tidak terdapat kekurangan dalam model ini, namun ahli memberikan masukan agar durasi video dalam model ini diberikan secukupnya agar tidak terlalu lama pada gerakan yang sama.

\section{Analisis Data Elang dan Anak Ayam}

Penilaian observasi ahli materi terhadap model elang dan anak ayam ini bahwa model ini masuk dalam katagori yang sangat 
baik. Beberapa ahli mempunyai pendapat yang sama dan menilai model ini sangat efektif untuk menanamkan kebutuhan yang ada dalam olahraga pencak silat meliputi komponen biomotor antara lain kekuatan, ketahanan, kecepatan, fleksibilitas dan kordinasi.

Selain itu model juga dapat mengembangkan ranah afektif seperti menanamkan unsur menyerang dan bertahan yang dibutuhkan dalam olahraga pencak silat. Unsur ini dapat melekat pada anak sehingga di kemudian hari ketika menjadi atlet pencak silat mempunyai unsur menyerang dan bertahan yang kuat.

Kemudian model juga mampu mengembangkan ranah kognitif seperti memunculkan ide baru, menemukan pengalaman dan hal penting yaitu bagaimana anak mempertahankan kemenangan dan cara apa yang harus dilakukan untuk mempertahankanya, tidak hanya mempertahankan kemenangan namun ranah kognitif seperti bagaimana anak untuk mencari kemenangan juga termuat dalam model ini.

Kesimpulan secara umum mengenai model yang digunakan dalam penelitian ini, bahwa model telah disesuaikan dengan kebutuhan, jenis gerakan, tujuan baik olahraga pencak silat ataupun olahraga tradisional yang menjadi pokok bahasan.

\section{Simpulan dan Saran}

Simpulan

Hasil penilaian para ahli materi terhadap model latihan yang dikembangkan melalui 2 (dua) kali uji coba dan dilakukan uji efektifitas skala nilai, dimana ahli memberikan penilaian terhadap model melalui skala nilai lebih dari $80 \%$. Arti dari pemberian skala nilai terhadap model lebih dari $80 \%$ bahwa model ini sudah layak digunakan dan dinyatakan sangat efektif sebagai model latihan keterampilan gerak pencak silat untuk anak 9-12 tahun.

Produk penelitian menghasilkan sebuah $\mathrm{CD}$ dan buku petunjuk pelaksanaan/buku pedoman yang di dalamnya terdapat 6 (enam) permainan. Beberapa permainan tersebut antara lain, (a) kucing dan tikus, (b) bentengan, (c) gobak sodor, (d) jala ikan, (e) berburu burung, (f) elang dan anak ayam.
Saran

Peneliti menyarankan agar latihan ini diberikan terhadap anak usia 9-12 tahun, sehingga sesuai antara karakteristik anak dengan kebutuhan cabang olahraga pencak silat.

Desiminasi hasil penelitian ini dibuat norma penilaian terhadap anak yang melakukan permainan ini sehingga pelatih mengetahui kemampuan anak terhadap keterampilan pencak silat.

\section{Daftar Pustaka}

Ardiwinata, A. A. dkk. (2006). Kumpulan permainan rakyat olahraga tradisional. Tangerang: Cerdas Jaya

Borg, Walter R., \& Gall R. (1983). Education research; An introduction $\left(4^{\text {Th }} \mathrm{ed}\right)$. New York: Longman.

Cholik M, Toho. (200). Gagasan-gagasan pendidikan jasmani dan olahraga. Surabaya: University Press Book G. Inc

Giriwijoyo, Santosa dkk. (2007). Ilmu kesehatan olahraga. Bandung: IKIP Bandung

Hariono, Awan. (2006). Metode melatih fisik pencak silat. Yogyakarta: FIK UNY

Hergenhanh, B .R, Matthew H. Olson. (2008). Theories of learning: Terjemahan Teori belajar (Edisi 7). Jakarta : Prenada Media Group.

Lubis, Johansyah. (2010). Teori latihan kondisi fisik umum. Penataran pelatih nasional pencak silat. Samarinda: PB IPSI.

Nawawi, Hadari \& Hadari, Martini. (2006). Instrumen penelitian bidang sosial. Yogyakarta: Gajah Mada University Press.

Rahman, Hari Amirulah. (2011). Kontribusi pembelajaran motorik dalam meningkatkan kualitas jasmani menuju pengembangan sumber daya manusia. Pidato Pengukuhan Guru Besar. Yogyakarta: UNY.

Soetoto P. (1999). Permainan anak, tradisional dan aktivitas ritmik. Jakarta. UT

Sukadiyanto. (2002). Metode melatih fisik petenis. Yogyakarta. FIK UNY. 